\title{
The influence of partial timber harvesting in riparian buffers on macroinvertebrate and fish communities in small streams in Minnesota, USA
}

\author{
Christopher J. Chizinski ${ }^{\mathrm{a}, *}$, Bruce Vondracek ${ }^{\mathrm{b}, 1}$, Charles R. Blinn $^{\mathrm{c}}$, Raymond M. Newman ${ }^{\mathrm{a}}$, \\ Dickson M. Atuke ${ }^{a}$, Keith Fredricks ${ }^{a}$, Nathaniel A. Hemstad ${ }^{a}$, \\ Eric Merten ${ }^{a}$, Nicholas Schlesser ${ }^{\mathrm{a}}$ \\ a Department of Fisheries, Wildlife, and Conservation Biology, University of Minnesota, 1980 Folwell Ave., St. Paul, MN 55108, USA \\ ${ }^{\mathrm{b}}$ US Geological Survey, Minnesota Cooperative Fish and Wildlife Research Unit, University of Minnesota, 1980 Folwell Ave., St. Paul, MN 55108, USA \\ c Department of Forest Resources, University of Minnesota, 1530 Cleveland Ave. North, St. Paul, MN 55108, USA
}

\section{A R T I C L E I N F O}

\section{Article history:}

Received 23 June 2009

Received in revised form 4 February 2010

Accepted 9 February 2010

\section{Keywords:}

Temporal variation

Rank-abundance

Timber harvest

Residual basal area

\begin{abstract}
A B S T R A C T
Relatively few evaluations of aquatic macroinvertebrate and fish communities have been published in peer-reviewed literature detailing the effect of varying residual basal area (RBA) after timber harvesting in riparian buffers. Our analysis investigated the effects of partial harvesting within riparian buffers on aquatic macroinvertebrate and fish communities in small streams from two experiments in northern Minnesota northern hardwood-aspen forests. Each experiment evaluated partial harvesting within riparian buffers. In both experiments, benthic macroinvertebrates and fish were collected 1 year prior to harvest and in each of 3 years after harvest. We observed interannual variation for the macroinvertebrate abundance, diversity and taxon richness in the single-basin study and abundance and diversity in the multiple-basin study, but few effects related to harvest treatments in either study. However, interannual variation was not evident in the fish communities and we detected no significant changes in the stream fish communities associated with partially harvested riparian buffers in either study. This would suggest that timber harvesting in riparian management zones along reaches $\leq 200 \mathrm{~m}$ in length on both sides of the stream that retains $R B A \geq 12.4 \pm 1.3 \mathrm{~m}^{2} \mathrm{ha}^{-1}$ or on a single side of the stream that retains $R B A \geq 8.7 \pm 1.6 \mathrm{~m}^{2}$ ha $\mathrm{a}^{-1}$ may be adequate to protect macroinvertebrate and fish communities in our Minnesota study systems given these specific timber harvesting techniques.
\end{abstract}

(c) 2010 Elsevier B.V. All rights reserved.

\section{Introduction}

Forested riparian areas are important ecotones, characterized by a gradient across an upland forest, a terrace-slope complex, floodplain, and the aquatic system. Typically, riparian areas constitute a small total area in a forested watershed, but at the watershed scale, can contribute significantly to species diversity and productivity (Naiman et al., 1993; Naiman and Décamps, 1997; Goebel et al., 2003). Any disturbance (e.g., timber harvesting) within this gradient has the potential to disrupt the intimate connection between the upland forest and riparian system (Richardson and Danehy, 2007). The recognition of the importance of the riparian area

\footnotetext{
* Corresponding author. Tel.: +1 6126264964.

E-mail address: chizi001@umn.edu (C.J. Chizinski).

1 The Unit is jointly sponsored by the U. S. Geological Survey, the University of Minnesota, the Minnesota Department of Natural Resources, the U. S. Fish and Wildlife Service, and the Wildlife Management Institute.
}

for biodiversity and fish habitat is highlighted by the extensive research related to effects of timber harvesting, particularly the role of historic clearcut practices.

Timber harvesting may result in increased stream sediment loads and altered stream morphology, stream temperature, and hydrology, which directly or indirectly lead to changes in flora and fauna. Increases in sedimentation or sediment load from timber harvesting may lead to a change in abundance of invertebrates (Noel et al., 1986; Brown et al., 1997) and fish (Davies and Nelson, 1994; Broadmeadow and Nisbet, 2004; Nislow and Lowe, 2006). Timber harvesting can modify instream habitat (Smokorowski and Pratt, 2007) or faunal communities (Murphy and Koski, 1989; Bilby and Ward, 1991) by altering the amount of coarse woody debris. Decreases in canopy cover over the stream, associated with the removal of riparian vegetation, can initially decrease the amount of allochthonous leaf input (Hawkins et al., 1982; Palik et al., 1999; Kedzierski and Smock, 2001), lead to greater light availability and hence, increase the amount of autochthonous energy production, and alter thermal regimes (Kiffney et al., 2003). Changes 
in the energy input associated with reduction in canopy cover can alter the invertebrate community such that it becomes dominated by grazers (Stone and Wallace, 1998), whereas altered thermal regimes can directly affect survival and reproduction of invertebrates and fish (Johnson and Jones, 2000; Kiffney et al., 2003).

Siliviculture practices typically include the implementation of riparian buffers along stream banks (Blinn and Kilgore, 2001; Lee et al., 2004) where timber harvesting operations are restricted or altered as compared to upland operations to mitigate impact on terrestrial and aquatic ecosystems. Riparian buffer width is typically dependent on the stream size to allow vegetation to stabilize banks, minimize the erosion of fine sediments into the channel, and provide shading which maintains the moderated microclimate (Anderson et al., 2007) and stream productivity. Additionally, riparian vegetation maintains allochthonous energy sources for invertebrates and fish in the form of leaf litter input and terrestrial invertebrates (Davies and Nelson, 1994; Broadmeadow and Nisbet, 2004). Although riparian buffers can minimize disruption to the aquatic communities following timber harvesting in the riparian area (Newbold et al., 1980; Quinn et al., 2004; Olson et al., 2007), the most effective width, vegetational composition, and residual tree densities are still largely unknown (Blinn and Kilgore, 2001; Broadmeadow and Nisbet, 2004; Lee et al., 2004).

We evaluated data from two experiments in northern Minnesota, USA, comparing the response of stream aquatic macroinvertebrate and fish communities to partially harvested riparian buffers and riparian control plots for 3 years following harvest in northern hardwood-aspen forests. The primary objectives were to: (1) evaluate the effectiveness of partial harvesting within the riparian buffer at mitigating disturbances to aquatic macroinvertebrates and fish communities; and (2) identify similarities or differences in responses to timber harvesting between invertebrate and fish communities.

\section{Methods}

\subsection{Experimental overview}

The study was conducted using two different experiments: a single-basin (1997-2000) and a multiple-basin (2003-2006) experiment. In this study, we do not directly compare each experiment because of variations in study design, harvest treatments, and sampling (as discussed below) but provide a synthesized comparison of the overall trends observed in each experiment to evaluate the role of partial harvesting on aquatic macroinvertebrate and fish communities.

\subsubsection{Single-basin experiment}

The single-basin experiment (Pokegama basin; Fig. 1) was a case study designed to investigate the effects of an intermediate residual basal area (RBA) (targeted harvest on both sides of the stream of $11.5 \mathrm{~m}^{2} \mathrm{ha}^{-1}$; actual realized RBA was $12.4 \mathrm{~m}^{2} \mathrm{ha}^{-1}$ ) in the riparian buffer on stream aquatic macroinvertebrate and fish communities. The experiment examined 12 treatment plots on four small streams, located entirely within the Northern Lakes and Forest Ecoregion (Omernik and Gallant, 1988) in Itasca County, MN that flows into Pokegama Lake (Table 1, Fig. 2). The forest ecosystem of this study area was predominately northern hardwood-aspen mixtures. Streams in this experiment were first and second order perennial streams with bankfull widths between 0.7 and $4.5 \mathrm{~m}$ and a $44 \mathrm{~m} / \mathrm{km}$ gradient. There was a history of logging in this area with same age stands at the time of harvest originating in the early 20th century (i.e., 70-80 years) (B. Palik, unpublished data). This study was initiated in 1997 (pre-harvest) and concluded in 2000 ( 3 years post-harvest).

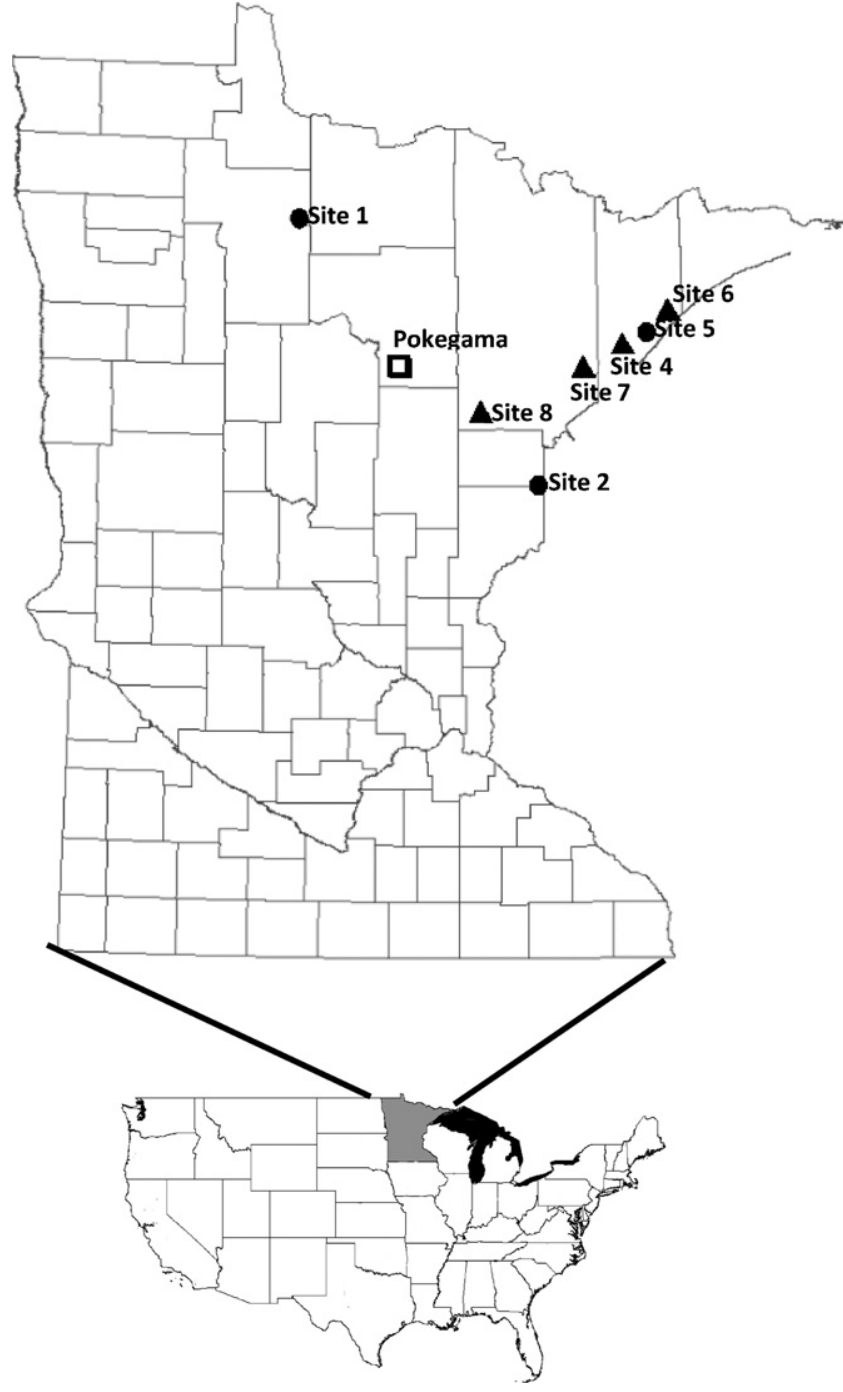

Fig. 1. Map of site locations included in the single- (open square) and multiple-basin (circles and triangles) experiments in northern Minnesota, USA. Circles represent sites harvested to an intermediate residual basal area (RBA) treatment and triangles represent sites harvested to a low RBA. Site descriptions are in Table 1.

The experiment incorporated the following three treatments: (1) a control, with an unharvested upland and unharvested riparian buffer; (2) riparian control, with an upland clearcut using the cut-to-length method and unharvested riparian buffer; (3) an intermediate RBA treatment with an upland clearcut and a riparian buffer treatment where trees were harvested using conventional harvesting equipment (feller-buncher and grapple skidder to a targeted goal of $11.5 \mathrm{~m}^{2} \mathrm{ha}^{-1}$ ) and cut-to-length timber harvesting equipment (processor and forwarder). Clearcut was defined as retaining less than $3.5 \mathrm{~m}^{2} \mathrm{ha}^{-1}$ to meet a silvicultural goal of regenerating aspen (Populus spp.) as suggested by Perala (1977). Harvest treatments were assigned to sites using a stratified restricted randomization; control sites could not be downstream from more than one harvested site, and treatments were stratified across the four streams (Fig. 2). Each treatment was replicated three times and randomly assigned among 12 plots on the four streams. Previous analysis of the differences in harvest methods (i.e., fellerbuncher with grapple skidders and cut-to-length processor with forwarders) indicated that there were no significant differences between the two harvest methods (Hemstad et al., 2008). As a result, harvested riparian buffers were treated as a single treatment group for this analysis. In addition, to compare to the multiple-basin 
Table 1

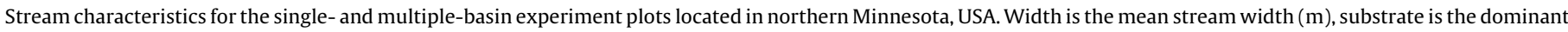
stream substrate, and timber species are the dominant pre-harvest tree species at the sampling locations.

\begin{tabular}{|c|c|c|c|c|c|}
\hline Stream name & Location & County & Width & Substrate & Forest type \\
\hline \multicolumn{6}{|l|}{ Single-basin experiment } \\
\hline Pokegama & & Itasca & 1.0 & Sand & Northern hardwoods and aspen \\
\hline \multicolumn{6}{|l|}{ Multiple-basin experiment } \\
\hline Shotley Brook & Site 1 & Beltrami & 4.6 & Sand & Northern hardwoods, aspen, and lowland hardwoods \\
\hline Nemadji State Forest & Site 2 & Carlton & 0.9 & Gravel, rock & Northern hardwoods and aspen \\
\hline West Split Rock River & Site 4 & Lake & 5.2 & Rock & Birch, aspen, lowland hardwoods, and balsam fir \\
\hline East Branch of Beaver River & Site 5 & Lake & 4.6 & Rock, bedrock & Birch, balsam fir, and aspen \\
\hline East Baptism River & Site 6 & Lake & 0.9 & Sand, gravel & Aspen, birch, and balsam fir \\
\hline Cloquet River tributary & Site 7 & St. Louis & 0.6 & Gravel, rock & Northern hardwoods, aspen, and lowland hardwoods \\
\hline St. Louis River tributary & Site 8 & St. Louis & 4.6 & Sand & Northern hardwoods, aspen, and lowland hardwoods \\
\hline
\end{tabular}

(A)

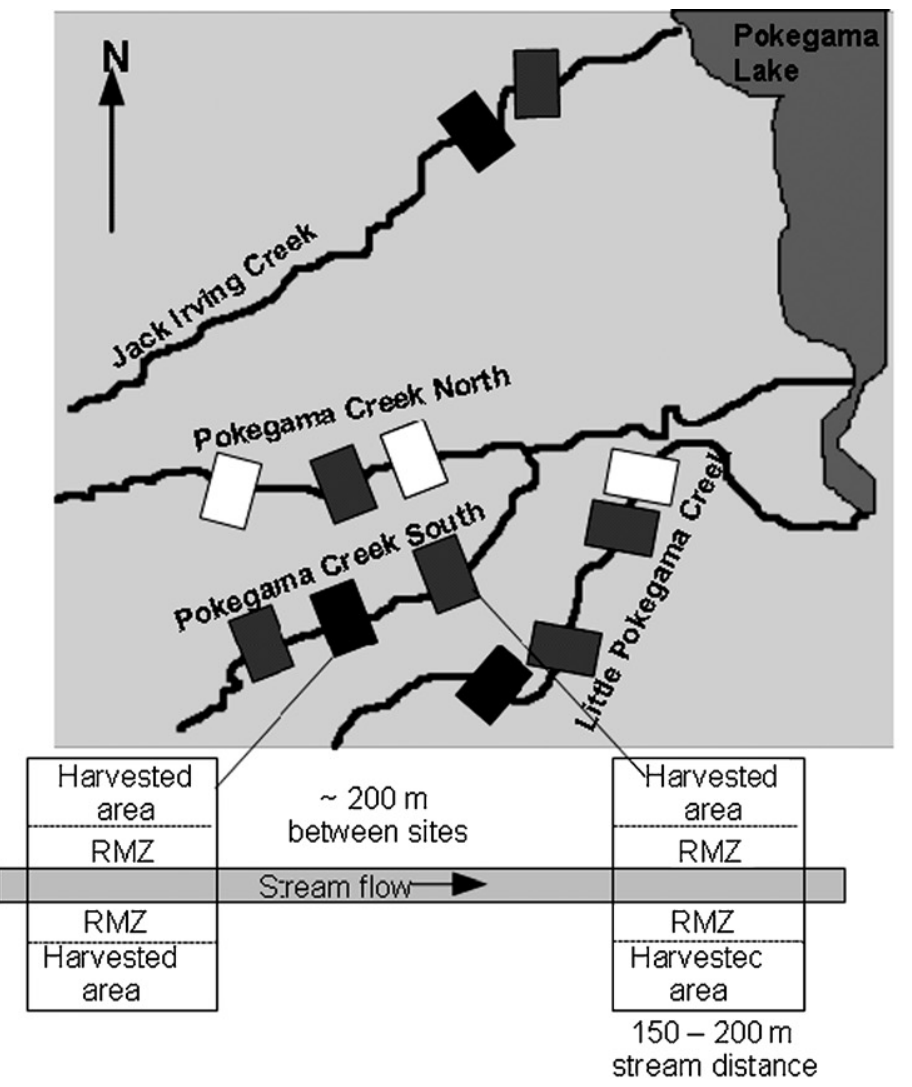

(B)

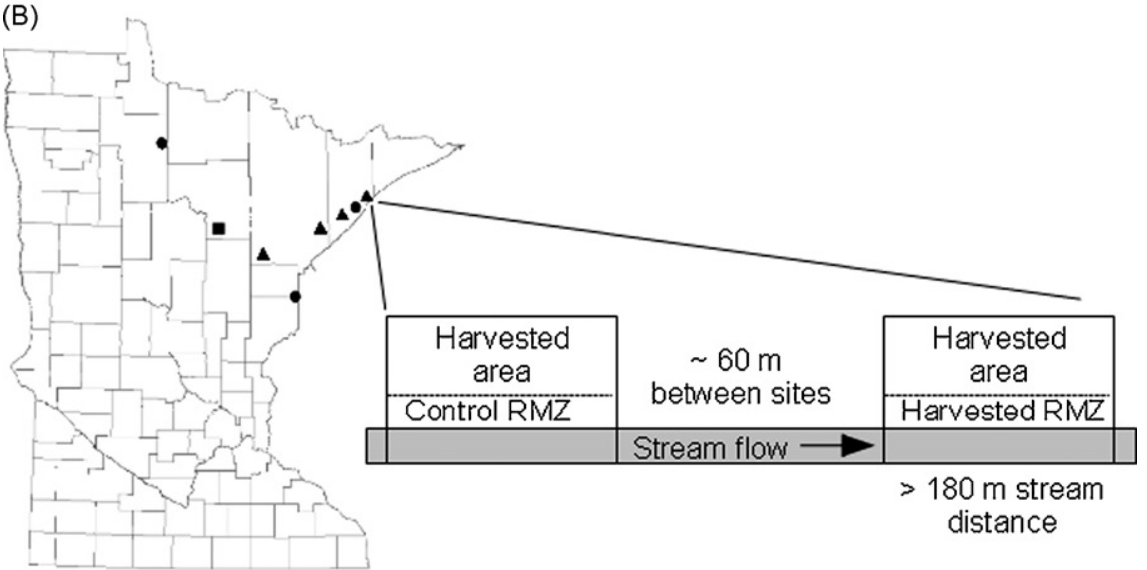

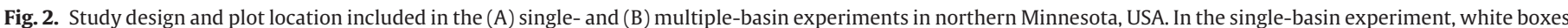

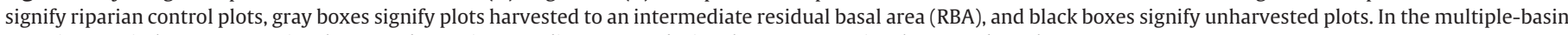
experiment, circles represent sites harvested to an intermediate RBA and triangles represent sites harvested to a low RBA. 

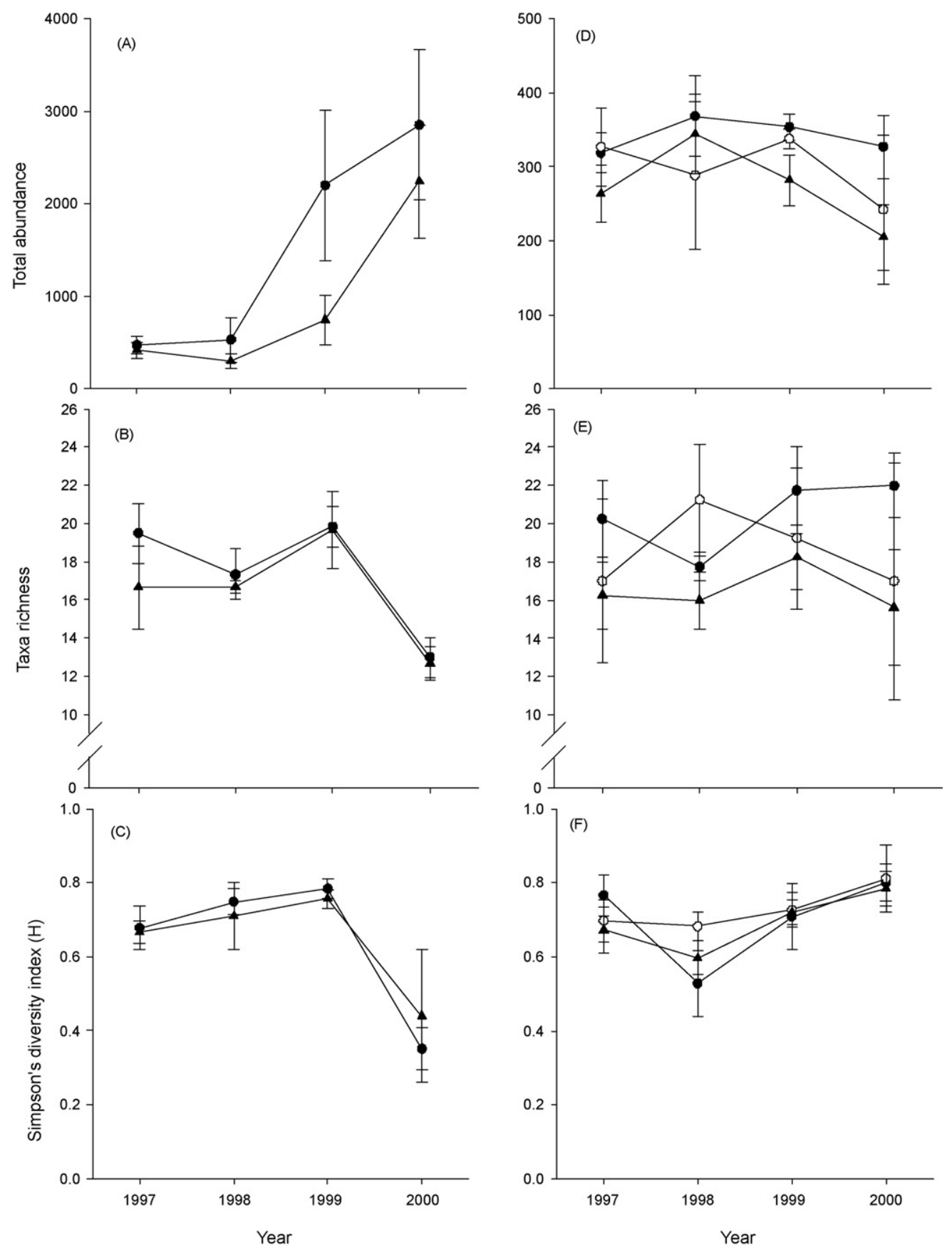

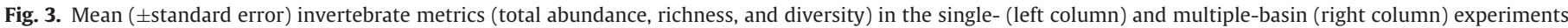

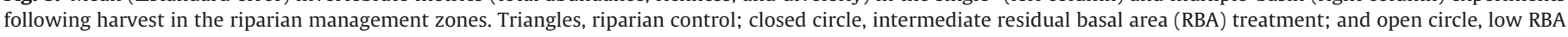
treatment.

experiment, only differences between the riparian control and the treatments were included in the analysis. Each harvested block was 4.9 ha (2.45 ha on each side of the stream) and the riparian buffer was $150-200-\mathrm{m}$ long and 30-m wide on each side of the stream. All treatment plots were separated by at least $200 \mathrm{~m}$ of stream length of unharvested forest. Pre-harvest data were collected in 1997 and timber harvesting occurred during late summer. Further details of the experimental design for this manipulation can be found in Palik et al. (2003) and Hemstad et al. (2008).

\subsubsection{Multiple-basin experiment}

The second experiment included multiple-basins and investigated the effects of intermediate RBA (targeted goal of $11.5 \mathrm{~m}^{2} \mathrm{ha}^{-1}$; actual realized RBA was $16.0 \mathrm{~m}^{2} \mathrm{ha}^{-1}$ ) and low RBA (targeted goal of $5.7 \mathrm{~m}^{2} \mathrm{ha}^{-1}$; actual realized RBA was $8.7 \mathrm{~m}^{2} \mathrm{ha}^{-1}$ ) in the riparian buffer on the macroinvertebrate and fish communities. This experiment was initiated to examine Minnesota state riparian buffer guidelines (Minnesota Forest Resources Council, 1999) across a broader geographic area than the single-basin experiment. There were seven streams located in Beltrami, Carlton, Cook, Lake, and St. Louis counties, MN (Table 1, Fig. 1). Six of the seven streams (East Baptism River, East Branch Beaver River, West Split Rock River, Cloquet River Tributary, St. Louis River Tributary, and Nemadji State Forest) were located within the Northern Lakes and Forest Ecoregion (Omernik and Gallant, 1988). The seventh stream, Shotley Brook, was located in the Northern Minnesota Wetlands Ecoregion. The forest ecosystems of all study areas were predominately northern hardwood-aspen mixtures. This experiment was 


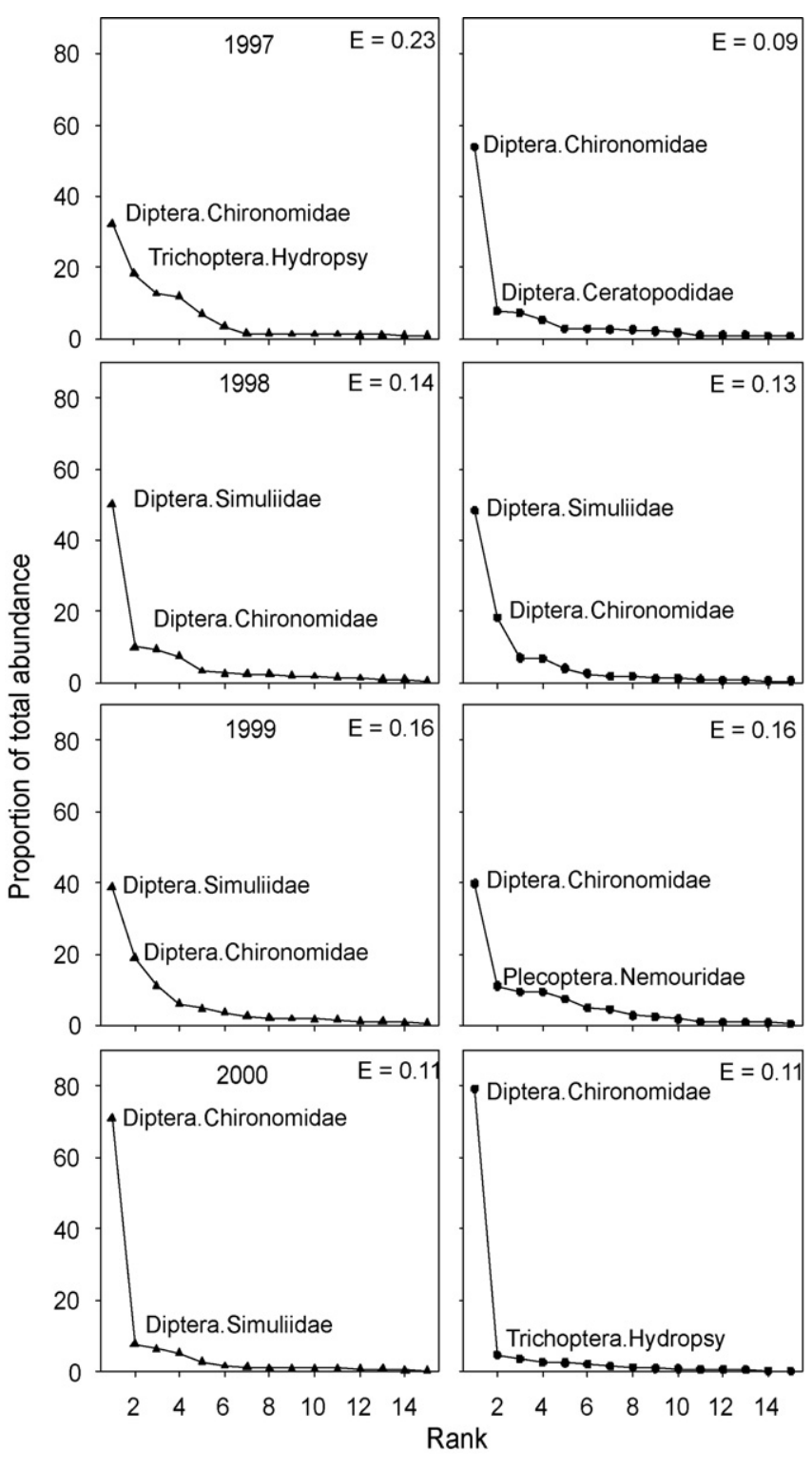

Fig. 4. Rank-abundance curve for the invertebrate taxa collected from the singlebasin experiment from 1997 (pre-harvest) to 2000 (3 years post-harvest). For the riparian control treatment (left column), the riparian buffer was unharvested with an upland clearcut. For the intermediate residual basal area (RBA) treatment (right column), the riparian buffer was thinned to an actual realized basal area of $12.4 \mathrm{~m}^{2} \mathrm{ha}^{-1}$. The Simpon's index of evenness $(E)$ for the community during the year is presented in the top right of each panel (see text for description).

initiated in 2003 (pre-harvest) and concluded in 2006 (3 years post-harvest). All streams in this experiment were first order to second order, perennial streams with bankfull widths between 0.9 and $10.5 \mathrm{~m}$. Streams included in this study were typically wider (mean $\pm \mathrm{SE} ; 3.0 \pm 0.8 \mathrm{~m}$ ) than streams in the single-basin experiment but had a similar gradient $(40 \mathrm{~m} / \mathrm{km})$. As with the single-basin experimental site, there was a history of logging in this area with the same age stands at the time of harvest originating in the early 20th century (i.e., 70-80 years) (B. Palik, unpublished data).

We used an incomplete block design with the riparian control and one of the two harvested treatments (intermediate RBA and a low RBA) nested within each site (Fig. 2). In all cases, the upland was clearcut. Clearcut was defined the same as in the single-basin experimental sites (i.e., RBA $<3.5 \mathrm{~m}^{2} \mathrm{ha}^{-1}$ ). The intermediate RBA treatment was replicated three times and the low RBA treatment was replicated four times for a total of 14 treatment plots. Each harvested plot was 3.2 ha located on one side of the stream and had a minimum of $180-\mathrm{m}$ of stream length. The riparian buffer was $180-\mathrm{m}$ long and $45-\mathrm{m}$ wide. All treatment plots were separated by a minimum of $60 \mathrm{~m}$ of unharvested forest and all riparian buffer-harvested plots were downstream from the riparian control plots. Timber harvesting operations commenced in mid-December 2003 and were completed by March 2004. All harvest operations were conducted on frozen ground when sufficient snow had accumulated, using conventional harvesting equipment (feller-buncher and grapple skidder).

\subsection{General study designs}

Each experiment included 1 year of pre-harvest data and 3 years of post-harvest data. In both experiments, the stream reach under investigation was the section immediately downstream of treatment.

\subsection{Aquatic macroinvertebrates}

In the single-basin experimental plots, invertebrate samples were taken mid-summer (late July or early August) in each year at random locations within two consecutive riffles using a $0.1 \mathrm{~m}^{2}$ Waters-Knapp Hess sampler with $500 \mu \mathrm{m}$ mesh. At each random location the substrates were stirred and scrubbed. Invertebrate samples were preserved in $95 \%$ ethanol and returned to the laboratory, where they were identified to the lowest practical taxon, typically genus (Merritt and Cummins, 1996). In the multiple-basin experimental plots, macroinvertebrates were sampled mid-summer (late July or early August) in each year using a 30.4-cm wide D-framed dipnet with $500 \mu \mathrm{m}$ mesh following standard EPA sampling protocol (Barbour et al., 1999). Sampling started downstream of the treatment plot and moved upstream to avoid impacting subsequent samples. Samples were collected after every $2.5 \mathrm{~m}$ of stream channel length for a total of 20 sampling points in a 50-m reach. Generally, two kicks were made per sampling point and all habitats available in the reach (e.g., riffle, pool) were sampled. Whenever a sampling point fell on boulders or any other large immovable object, the object was scrubbed and invertebrates were washed into the dipnet. Whenever it was difficult to sample using kicks, such as between boulder pockets, the bottom substrates were stirred by hand, and released materials and organisms floated into the D-net. Samples were emptied regularly into a bucket to avoid losing invertebrates prior to collecting at the next sampling point. Invertebrate samples were preserved in $80 \%$ ethanol and returned to the laboratory where they were identified to the lowest practical taxon, typically genus.

\subsection{Fish}

In the single-basin experimental plots, fish were sampled in August with a Wisconsin ${ }^{\mathrm{TM}} \mathrm{Abp}-3$ pulsed DC backpack electrofisher (Engineering Technical Services). At each site, fish were collected from a 50-m long reach within the treatment plot with a single pass. Fish were identified to species and returned to the stream. In the multiple-basin experimental plots, fish were sampled once a year (August) with the same backpack electrofisher from a 100-m reach with a single pass. Fish were identified to species and returned to the stream. The number of fish per sample was standardized to a $50-\mathrm{m}$ reach of the stream $\left(n \cdot 50 \mathrm{~m}^{-1}\right)$.

\subsection{Statistical analyses}

We compared aquatic macroinvertebrate and fish metrics between treatments using mixed models in $\mathrm{R}$ using the nlme package (Pinheiro et al., 2009) for each experiment separately. For 

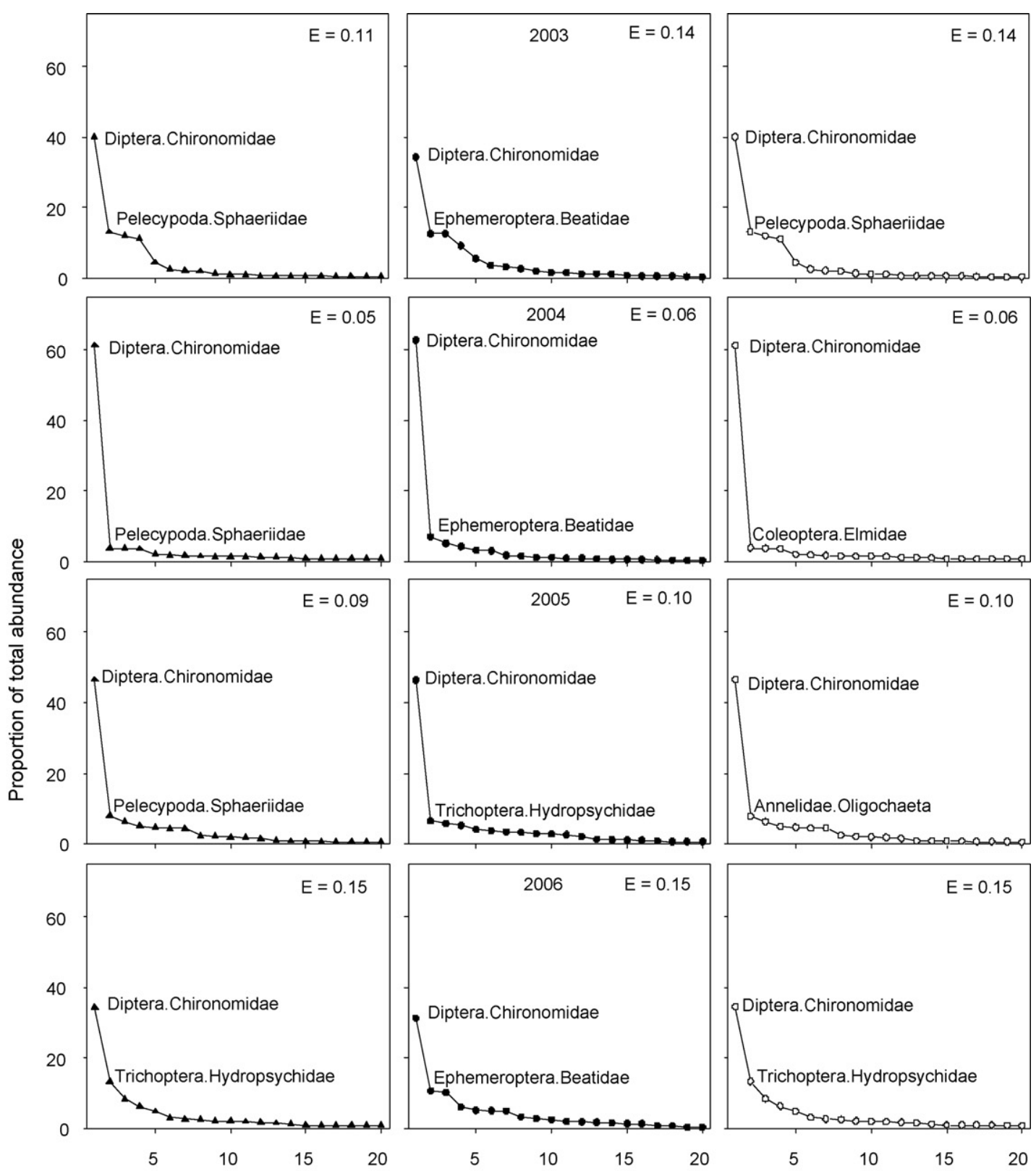

Rank

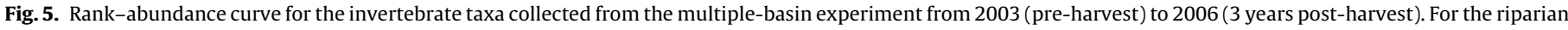

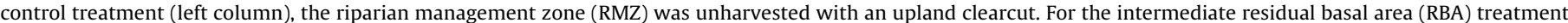

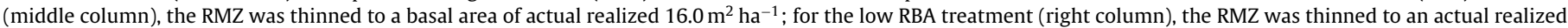
basal area of $8.7 \mathrm{~m}^{2} \mathrm{ha}^{-1}$. The Simpon's index of evenness $(E)$ for the community during the year is presented in the top right of each panel (see text for description).

the analysis of aquatic macroinvertebrates, we focused on relative abundance, richness, and diversity (Simpson D) at the family level. Although most taxa were identified to the genus level, we performed analyses at the family to incorporate macroinvertebrates that were only identified to the family level. For the analysis of fish, we focused on abundance, taxa richness, diversity (Simpson D) at the species level. Analyses were separated between experiments because of the different experimental designs that required different blocking protocols. For the single-basin experiment, we modeled the community metrics as a function of treatment (TRT) and year since harvest (YearSince) as a covariate. In this analysis, we blocked by stream, which was included as a random effect. In the multiple-basin experiment, the main effects were identical to the single-basin experiment but each treatment was nested by site (a random effect). We assessed statistical significance of all analyses at $\alpha=0.05$.

Rank-abundance curves (RAC, Whittaker, 1965; Magurran, 2004) were generated for invertebrate (family level) and fish (species level) communities at each experiment, treatment and year using the BiodiversityR package for $\mathrm{R}$ (Kindt and Coe, 2005). We visually inspected the proportional abundance for each taxon plotted against the corresponding abundance ranking. The RAC provides a visual depiction of taxa abundance within a community and can highlight dominant taxa or taxa shifts in the community. Within RAC, diversity is maximized when the slope of the curve approaches zero. Highly skewed distributions (i.e., slopes increasingly negative) indicate a decrease in the community evenness. In addition to using RAC to visually depict the communities, we calcu- 

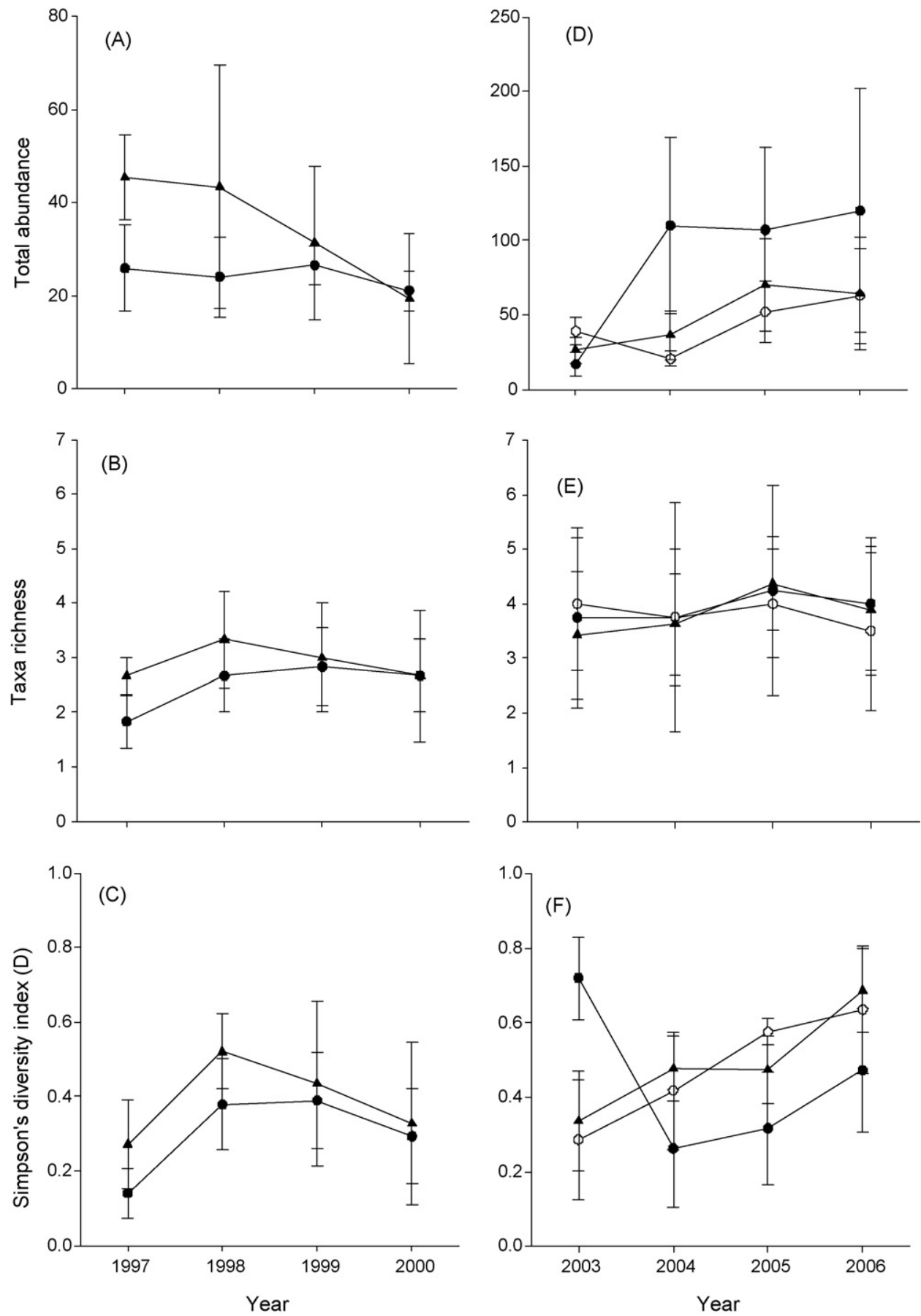

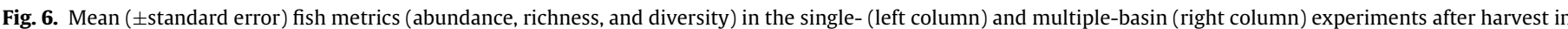
the riparian management zones. Triangles, riparian control; closed circle, intermediate residual basal area (RBA) treatment; and open circle, low RBA treatment.

lated Simpson's measure of evenness (E)(Simpson, 1949; Smith and Wilson, 1996). Index values range from near 0 (patchy or skewed) to 1 (even), and the index is relatively unaffected by sites with few individuals.

\section{Results}

\subsection{Aquatic macroinvertebrates}

A total of 44 aquatic macroinvertebrate taxa were collected in the single-basin experiment and 91 in the multiple-basin experiment (Appendix A). Overall, macroinvertebrate metrics displayed no significant effect of harvest treatment in either experiment
(Fig. 3). Total macroinvertebrate abundance increased substantially after harvest $\left(F_{2,26}=38.022 ; P<0.001\right)$ but did not vary by treatment $\left(F_{1,7}=0.613 ; P>0.05\right)$ in the single-basin experiment and this trend was less apparent in the multiple-basin experiment, but there was indication of a temporal $\left(F_{1,53}=5.021 ; P<0.05\right)$ but no significant treatment effect $\left(F_{1,53}=0.484 ; P>0.05\right)$. Taxa richness indicated strong temporal effects $\left(F_{1,26}=10.900 ; P<0.01\right)$ and no significant treatment effects $\left(F_{1,7}=0.23 ; P>0.05\right)$ in the single-basin experiment, whereas there was no significant tempo$\operatorname{ral}\left(F_{1,53}=1.637 ; P>0.05\right)$ or treatment effect $\left(F_{2,53}=1.069 ; P>0.05\right)$ in the multiple-basin experiment. Macroinvertebrate diversity tended to increase with years since harvest $\left(F_{1,26}=9.75 ; P<0.001\right)$ but did not vary among the treatments $\left(F_{1,7}=0.003 ; P>0.05\right)$ in 
the single-basin experiment or in the multiple-basin experiment (treatment: $F_{2,53}=0.456 ; P>0.05 ;$ years since harvest: $F_{1,53}=7.442$; $P<0.01$ ).

The aquatic macroinvertebrate communities in the singlebasin experiment were dominated by Chironimidae and Simulidae throughout the experiment (Fig. 4), indicated by the relatively low $(<25 \%) E$ throughout the 4 years of the study. Macroinvertebrate communities were initially dominated by Chironomidae along both the riparian control and the intermediate treatment prior to harvest. Following harvest, the proportion of Chironimidae decreased and the proportion of Simulidae increased. The dominance of Simulidae persisted in the riparian control plot the following year but Simulidae were replaced by Chironimidae in the intermediate control. In 2000 ( 3 years following harvest), there was a substantial increase in the dominance of Chironimidae ( $>70 \%$ of total abundance). While there were some changes were observed at the family level, it is very likely that more substantial changes occurred at lower taxonomic levels.

Likewise, macroinvertebrate communities in the multiple-basin experiment were dominated by Chironimidae throughout the experiment (Fig. 5) and had relatively low $E(<0.15)$. This was most strikingly observed the year after harvest where the macroinvertebrate community substantially shifted towards dominance by Chironimidae ( $>60 \%$ ) and a drop in $E$ to 0.05 or 0.06 (depending on treatment). In the two subsequent years ( 2 and 3 years after harvest), dominance by Chironimidae decreased with a corresponding increase in the index of community evenness $(E=0.15)$.

\subsection{Fish}

Six fish species were collected in the single-basin experiment and 17 were collected in the multiple-basin experiment (Appendix B). All fish taxa in the single-basin experiment were also collected in the multiple-basin experiment. As with the invertebrate metrics, fish metrics indicated a lack of significant effect relative to treatments but also indicated much less temporal variation (Fig. 6). Total fish abundance in the single-basin experiment did not indicate a significant temporal $\left(F_{1,26}=0.946 ; P>0.05\right)$ or treatment effect $\left(F_{1,7}=0.147 ; P>0.05\right)$. Likewise, in the multiplebasin experiment there was no indication of significant temporal $\left(F_{1,52}=1.106 ; P>0.05\right)$ or treatment $\left(F_{2,53}=0.829 ; P>0.05\right)$ effects on total fish abundance. Taxa richness (species) and diversity were not statistically significant temporally (richness: $F_{1,26}=0.718$; $P>0.05$; diversity: $F_{1,26}=1.271 ; P>0.05$ ) or by treatment (richness: $F_{1,7}=0.289 ; P>0.05$; diversity: $F_{1,7}=0.289 ; P>0.05$ ). Taxa richness was relatively consistent in the multiple-basin experiment with a mean of four species per year following harvest and did not indicate significant temporal $\left(F_{1,52}=1.106 ; P>0.05\right)$ or treatment effect $\left(F_{2,52}=0.827 ; P>0.05\right)$. Diversity increased in the riparian control and low treatment following harvest but diversity in the intermediate treatment substantially dropped in the first year after harvest and then began to increase. As such, there was no difference among treatments $\left(F_{2,52}=0.223 ; P>0.05\right)$ but there was an indication of a significant temporal effect $\left(F_{1,52}=4.150 ; P<0.05\right)$ in the multiplebasin experiment.

In the single-basin experiment the fish communities were initially dominated by the brook stickleback (Culaea inconstans Kirtland) (Fig. 7). One year after harvest, the proportion of the total abundance of the stickleback declined in the riparian control. Evenness in the riparian control increased from $E=0.53$ to 0.83 one year after harvest following the decline of the brook trout (Salvelinus fontinalis Mitchill) and the increase in proportion by northern redbelly dace (Phoxinus eos Cope). Alternatively, the northern redbelly dace declined in the intermediate treatment 1 year after harvest and the brook trout increased in abundance. Three years after harvest, the brook stickleback increased in relative abundance in both

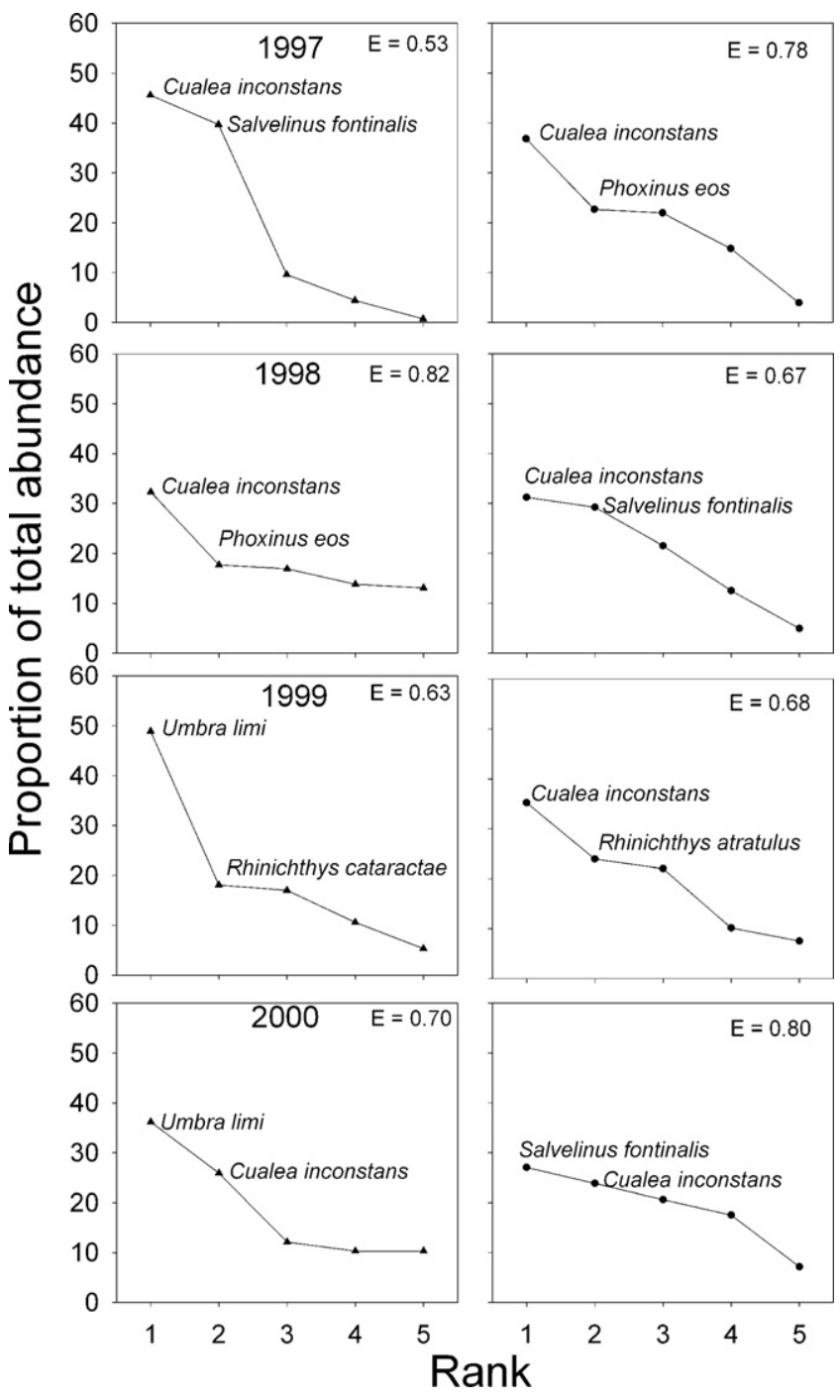

Fig. 7. Rank-abundance curve and the two most abundant fish species collected from the single-basin experiment from 1997 (pre-harvest) to 2000 ( 3 years postharvest). Within the riparian control treatment (left column), the riparian management zone (RMZ) was unharvested with a clearcut upland. Within the intermediate residual basal area (RBA) treatment (right column), the RMZ was thinned to an actua realized basal area of $12.4 \mathrm{~m}^{2} \mathrm{ha}^{-1}$. The Simpon's index of evenness $(E)$ for the community during the year is presented in the top right of each panel (see text for description).

the riparian control and the intermediate treatments but did not dominate the fish population.

In the multiple-basin experiment, community evenness was lower $(E=0.38-0.51)$ (Fig. 8) than that observed in the singlebasin experiment. The communities tended to be dominated by longnose dace (Rhinichthys cataractae Valenciennes) or blacknose dace ( $R$. atratulus Hermann) throughout the course of the experiment. One year after harvest, there was a large influx of rainbow trout (Oncorhynchus mykiss Walbaum) in the riparian control and intermediate treatment but these were not observed in the low treatments, likely because they were stocked by management agencies. Alternatively, there was an increase in brook trout in the low treatment but a similar increase was not observed in the riparian control or the intermediate treatment.

\section{Discussion}

Riparian buffers have become an important management practice utilized to minimize the negative effects (e.g., altered sediment 


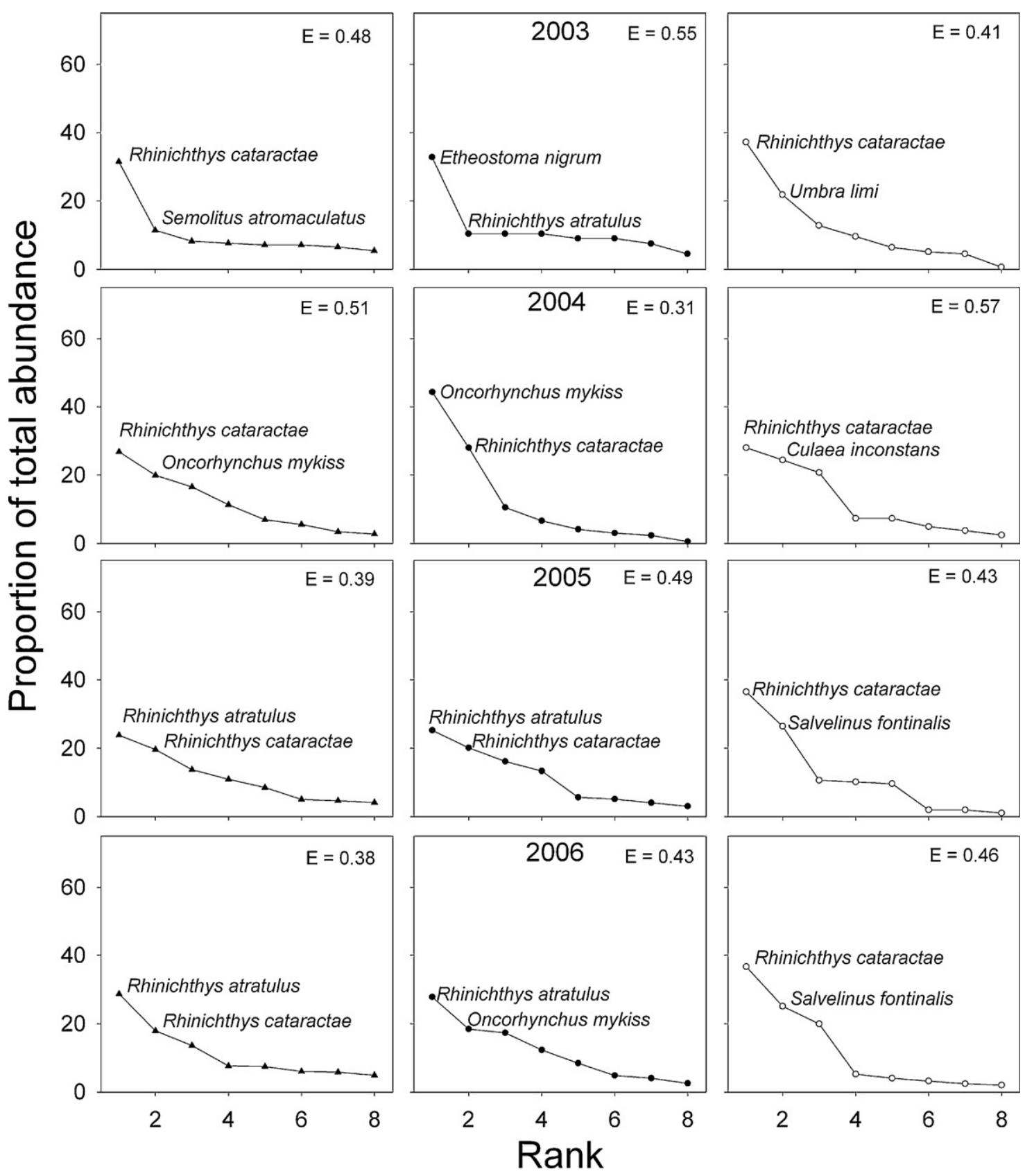

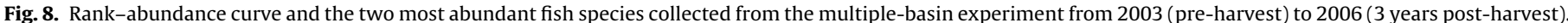

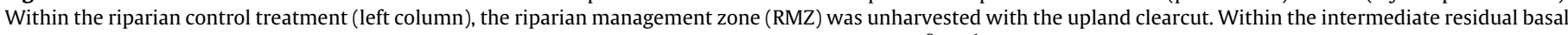

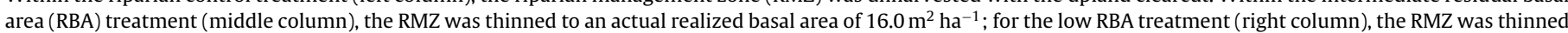

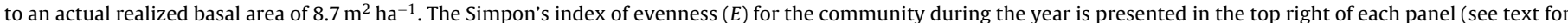
description).

loads, stream morphology, stream temperature, and hydrology) of timber harvesting on the riparian ecosystem. Multiple studies have investigated the effects of riparian buffer width and morphologies to protect various aspects of the riparian community (see Lee et al., 2004; Olson et al., 2007), which depend on the function that the buffer is meant to serve (Rykken et al., 2007), as well as site-specific conditions. This study investigated the role of three riparian buffers on preserving the biodiversity and community structure of aquatic macroinvertebrate and fish assemblages in Minnesota streams. In the single-basin experiment, riparian buffers $(150-\mathrm{m}$ long $\times 30$-m wide) were harvested to an intermediate basal area (i.e., $11.5 \mathrm{~m}^{2} \mathrm{ha}^{-1}$ ) and retained on both sides of the stream. In the multiple-basin experiment, one of the treatments was a riparian buffer $(180-\mathrm{m}$ long $\times 45$-m wide) harvested to an intermediate RBA (i.e., $11.5 \mathrm{~m}^{2} \mathrm{ha}^{-1}$ ) and the other treatment was harvested to a low RBA (i.e., $5.7 \mathrm{~m}^{2} \mathrm{ha}^{-1}$ ). In both of these treatments harvest only occurred on a single side of the stream. The buffer widths used in these experiments (i.e., 30 and $45 \mathrm{~m}$ ) fall within the midpoint of the range of published recommended widths (6 to >90 m; Lee et al., 2004; Olson et al., 2007) and are representative of Minnesota's Best Management Practices (Minnesota Forest Resources Council, 1999). In addition to being consistent with buffer size, partial harvesting within the riparian buffer is a commonly practiced technique. Partial harvesting within riparian buffers occurs in approximately $80 \%$ of all jurisdictions within the United States and Canada (Lee et al., 2004). Among these riparian buffers, the width of buffers used in the single-basin and multiplebasin experiments were larger than buffers that permitted partial 
harvesting within the United States and Canada (27.4 m) (Lee et al., 2004).

In both of the experiments from this study, there was some indication that the basal area reduction was not uniform across the riparian buffers. There tended to be a residual pattern that increased from upland to the stream (Kastendick, 2005). The reason for this pattern was primarily due to harvesting logistics within the riparian buffer (B. Palik, unpublished data). Trees that fell within a corridor that was the width of the crown for a mature tree immediately adjacent to the steam were not harvested. The rest of the harvest was dictated by site conditions. In addition, the potential for wet soil increased closer to the stream, which restricted movement of harvesting equipment; thus, more trees were removed farther from the stream where seeps or wet spots were less likely to occur. Topography was also important in determining which trees could be harvested and often an equipment operator could not harvest steep slopes into the riparian buffer. If access was difficult to the lower terraces nearer the stream, trees were left uncut. In future experiments that explore retaining different levels of timber in the riparian buffer, the pattern of retained timber should be compared to the effects of on riparian communities.

Residual timber density within the riparian buffer (i.e., treatments) consistently did not significantly affect aquatic biodiversity among fish species or at the family level among aquatic macroinvertebrates in both of our experimental studies, whereas interannual variability was not entirely consistent between the two experiments. Temporal variation was strongest in the macroinvertebrate community and in the single-basin experiment. Strong temporal variability of macroinvertebrate and fish communities has been observed in many stream systems (e.g., Wiens, 1981; Robinson et al., 2001; Bêche et al., 2006; Mykrä et al., 2008). Temporal variability observed at the individual taxa level is often associated with the variability of numerous instream habitat variables (Mykrä et al., 2008), particularly in intermittent stream systems (Bêche et al., 2006) and headwater streams (Robinson et al., 2001). Small-to-medium headwater streams may be expected to contain dynamic communities controlled by regional-scale dispersal processes (Palmer et al., 1996) because of their highly variable environments with frequent and often unpredictable disturbances. Interestingly, temporal effects were observed on instream habitat variables in the single-basin experiment (Hemstad et al., 2008), but there was a smaller effect in the multiple-basin experiment (Atuke, 2008.) A possible explanation for the high temporal variation of instream habitat may be more dynamic and disturbed watershed in the single-basin plots than the multiple-basin plots. The history of logging is likely not an explanation because the historic impact of logging within the two experiments was similar. The single-basin experiment streams were not as wide on average as in the multiple-basin experiment, potentially making these smaller streams more susceptible to disturbance (i.e., flashier) (Gomi et al., 2002). In accordance with the results of this study, we would expect that the initial (pre-harvest) richness, diversity, and abundance in the single-basin experiment would be less than observed in the preharvest collection in the multiple-basin experiment because of the history of disturbance in the system.

Instream habitat variables that indicated strong temporal variation (Hemstad et al., 2008; Atuke, 2008) may have been influential in driving the variability in the invertebrate communities. One factor commonly associated with changes in aquatic invertebrate communities is the opening of the canopy and a subsequent temperature increase in water temperatures (Johnson and Jones, 2000). Mean basal area in the intermediate RBA treatment in the singlebasin experiment was reduced by $59 \%$ but only corresponded to an $8 \%$ loss in canopy cover 3 years post-harvest. This reduction in canopy cover was not enough to significantly change stream temperatures (Hemstad et al., 2008). However, Hemstad et al. (2008) noted an increase in the amount of fine sediments in the singlebasin experiment but the effects were more related to temporal variation than to treatment effects. The $13 \%$ reduction in mean basal area at the intermediate RBA treatments resulted in a decrease in canopy cover by $13 \%$ three years post-harvest at the multiplebasin study. Likewise, the low RBA treatment mean basal area was reduced by $56 \%$ but resulted in a $7 \%$ loss in canopy cover after 3 years post-harvest. As for the single-basin experiment, there was no significant increase in stream temperatures (Atuke, 2008). Thus, it appears likely that the lack of significant changes in stream temperatures may have been influential on mitigating changes in the invertebrate and fish communities. One limitation in our data was that sampling occurred during 1 month in the summer for fish and macroinvertebrates and could have heightened the temporal nature observed in our data. Possibly strong temporal variation observed in the invertebrate community may have masked or confounded the treatment effect in the harvested riparian buffers (Wiens, 1981; Olden et al., 2006). In addition, because we could only analyze the invertebrate data at the family level there may have been much greater variation observed at the species level. However, given that we assessed the influence of partially harvested riparian buffers at many locations across northern Minnesota, it appears that the partial harvest did not result in substantial disturbances relative to unharvested riparian buffers in the invertebrate communities in these small-to-medium headwater streams.

Although buffer dimension size has received attention in the published literature, fewer studies have investigated the role of varying timber retention in the riparian management zones on riparian ecosystems or biological communities (e.g., Blinn and Kilgore, 2001; Broadmeadow and Nisbet, 2004; Wang et al., 2006) despite timber retention being a common practice in the United States and Canada (Lee et al., 2004). In comparisons of each of the buffer treatments to riparian controls, we were unable to detect differences between the riparian control and buffer (i.e., treatment effects) on the macroinvertebrate or fish communities in the streams at least within the time frame of this study ( $<3$ years). This would suggest that timber harvesting in riparian management zones along reaches $\leq 200 \mathrm{~m}$ in length on both sides of the stream that retains $R B A \geq 12.4 \pm 1.3 \mathrm{~m}^{2} \mathrm{ha}^{-1}$ or on a single side of the stream that retains $R B A \geq 8.7 \pm 1.6 \mathrm{~m}^{2} \mathrm{ha}^{-1}$ may be adequate to protect macroinvertebrate and fish communities in our Minnesota study systems given these specific timber harvesting techniques. However, broad inferences from this study should be restricted because these were case studies in northern hardwood forests and could be influenced by multiple site-specific harvest and environmental factors. The large temporal variation observed in the instream habitat and invertebrate and fish communities were typical of these types of systems, but could have confounded treatments effects (Grossman et al., 1990). This difficulty may have been influenced by only having 1-year pre-harvest data for both experiments. While studies only including 1-year pre-harvest data in the published literature are common (e.g., Wang et al., 2006; Wilkerson et al., 2006; de Graaf and Roberts, 2008), we attempted to overcome this limitation by examining across a larger spatial extent. The large number of plots included in our study and the relative consistency of our results suggest that the treatment effects were minimal. However, the relatively small size of our treatment plots and short lengths of stream reach harvested (although the sizes of harvest blocks are typical for the region) may have limited the impacts of harvest as compared to what has been observed in larger harvest treatments (Barton et al., 1985; Carroll et al., 2004). For example, Carroll et al. (2004) observed significant increases in stream water temperatures where timber harvesting occurred on both sides of the stream, although there were no significant changes in stream temperature observed where harvesting occurred on a single side. Further studies that examine the effect of partially harvested ripar- 
ian buffers on mitigating impacts on aquatic biodiversity should consider the effects of larger harvested plots (i.e., greater impact to the riparian system) and harvest along longer reaches and include multiple years of pre-harvest data to identify the natural temporal variation observed in the communities.

\section{Acknowledgements}

We thank Matthew Ihnken, Robert Dodd, and Scott Haire for assistance in the field and the laboratory. Brian Palik, Jim Perry, and Dave Zumeta provided helpful comments on an earlier draft of this manuscript. Brian Palik and personnel at the US Forest Service Northern Research Station were instrumental in setting up the studies. Partial funding for this project was provided by the Minnesota Department of Natural Resources Section of Fisheries, Minnesota Environment and Natural Resources Trust Fund as recommended by the Legislative-Citizen Commission on Minnesota Resources (LCCMR), Minnesota Forest Resources Council, and Minnesota Trout Unlimited. Reference to trade names does not imply endorsement by authors or the U.S. Government.

\section{Appendix A.}

Taxa recorded at the single-basin and multiple-basin experimental sites in northern Minnesota. RC indicates the riparian control sites, INT indicates the intermediate RBA treatments, and Low indicates the low RBA treatments. A one indicates that the species was present in the treatment and a zero indicates an absence in the treatment.

\begin{tabular}{|c|c|c|c|c|c|}
\hline \multirow[t]{2}{*}{ Taxa } & \multicolumn{2}{|c|}{ Single basin } & \multicolumn{3}{|c|}{ Multiple basin } \\
\hline & $\mathrm{RC}$ & INT & $\mathrm{RC}$ & INT & Low \\
\hline Annelidae.Hirudinea & 1 & 1 & 1 & 1 & 1 \\
\hline Annelidae.Oligochaeta & 0 & 0 & 1 & 1 & 1 \\
\hline Arachnidae & 1 & 0 & 0 & 0 & 1 \\
\hline Coleoptera.Chrysomelidae & 0 & 0 & 1 & 0 & 1 \\
\hline Coleoptera.Curculionidae & 1 & 1 & 1 & 1 & 1 \\
\hline Coleoptera.Dryopidae & 1 & 1 & 1 & 0 & 1 \\
\hline Coleoptera.Dytiscidae & 0 & 0 & 1 & 1 & 1 \\
\hline Coleoptera.Elmidae & 0 & 0 & 1 & 1 & 1 \\
\hline Coleoptera.Haliplidae & 0 & 0 & 1 & 1 & 1 \\
\hline Coleoptera.Hydraenidae & 0 & 0 & 1 & 1 & 1 \\
\hline Coleoptera.Hydrophilidae & 0 & 0 & 1 & 1 & 1 \\
\hline Coleoptera.Scirtidae & 0 & 0 & 1 & 1 & 0 \\
\hline Coleoptera.Staphylinidae & 1 & 1 & 0 & 1 & 0 \\
\hline Collembola.Entomybridae & 0 & 0 & 1 & 0 & 1 \\
\hline Collembola.Isotomidae & 0 & 0 & 1 & 1 & 1 \\
\hline Collembola.Poduridae & 1 & 1 & 0 & 1 & 0 \\
\hline Collembola.Sminthuridae & 1 & 1 & 0 & 0 & 0 \\
\hline Collembola.unknown & 0 & 0 & 0 & 1 & 0 \\
\hline Amphipoda.Gammaridae & 0 & 0 & 0 & 0 & 1 \\
\hline Crustacea.Cladocera & 0 & 0 & 0 & 0 & 1 \\
\hline Diptera.Athericidae & 1 & 1 & 1 & 1 & 1 \\
\hline Diptera.Atheridae & 0 & 0 & 0 & 1 & 1 \\
\hline Diptera.Ceratopodidae & 1 & 1 & 1 & 1 & 1 \\
\hline Diptera.Chironomidae & 0 & 0 & 1 & 1 & 1 \\
\hline Diptera.Culicidae & 0 & 0 & 1 & 1 & 1 \\
\hline Diptera.Dixidae & 0 & 1 & 1 & 1 & 1 \\
\hline Diptera.Dolichopodidae & 1 & 1 & 0 & 0 & 0 \\
\hline Diptera.Empididae & 0 & 0 & 1 & 1 & 1 \\
\hline Diptera.Ephydridae & 0 & 0 & 0 & 1 & 1 \\
\hline Diptera.Ptychopteridae & 1 & 1 & 0 & 0 & 0 \\
\hline Diptera.Simuliidae & 0 & 0 & 1 & 1 & 1 \\
\hline Diptera.Stratiomyidae.2 & 1 & 1 & 0 & 0 & 0 \\
\hline Diptera.Syrpidae & 1 & 1 & 0 & 0 & 0 \\
\hline Diptera.Tabanidae & 0 & 0 & 1 & 0 & 1 \\
\hline Diptera.Tipulidae & 1 & 1 & 1 & 1 & 1 \\
\hline Diptera.unknown & 0 & 0 & 0 & 0 & 1 \\
\hline Ephemeroptera.Beatidae & 0 & 0 & 1 & 1 & 1 \\
\hline Ephemeroptera.Baetiscidae & 0 & 0 & 1 & 0 & 1 \\
\hline Ephemeroptera.Caenidae & 0 & 0 & 1 & 1 & 1 \\
\hline Ephemeroptera.Ephemerellidae & 0 & 0 & 1 & 1 & 1 \\
\hline
\end{tabular}

Appendix A (Continued)

\begin{tabular}{|c|c|c|c|c|c|}
\hline \multirow[t]{2}{*}{ Taxa } & \multicolumn{2}{|c|}{ Single basin } & \multicolumn{3}{|c|}{ Multiple basin } \\
\hline & $\mathrm{RC}$ & INT & $\mathrm{RC}$ & INT & Low \\
\hline Ephemeroptera.Ephemeridae & 0 & 0 & 1 & 1 & 1 \\
\hline Ephemeroptera.Heptageniidae & 0 & 1 & 1 & 1 & 1 \\
\hline Ephemeroptera.Isonychidae & 0 & 0 & 1 & 1 & 1 \\
\hline Ephemeroptera.Leptophlebiidae & 0 & 0 & 1 & 1 & 1 \\
\hline Ephemeroptera.Siphlonuridae & 0 & 0 & 0 & 1 & 1 \\
\hline Ephemeroptera.Tricorythidae & 0 & 0 & 1 & 1 & 1 \\
\hline Ephemeroptera.unknown & 0 & 0 & 0 & 1 & 0 \\
\hline Gastropoda.Amnicolidae & 0 & 1 & 0 & 0 & 0 \\
\hline Gastropoda.Ancylidae & 0 & 0 & 1 & 1 & 1 \\
\hline Gastropoda.Linadiidae & 1 & 1 & 0 & 0 & 0 \\
\hline Gastropoda.Lymnaeidae & 0 & 1 & 0 & 0 & 0 \\
\hline Hemiptera.Aphididae & 0 & 0 & 1 & 1 & 0 \\
\hline Hemiptera.Belostomatidae & 0 & 0 & 1 & 0 & 1 \\
\hline Hemiptera.Cicadellidae & 1 & 0 & 1 & 0 & 0 \\
\hline Hemiptera.Corixidae & 0 & 1 & 0 & 0 & 1 \\
\hline Hemiptera.Gerridae & 1 & 0 & 1 & 1 & 1 \\
\hline Hemiptera.Hebridae & 0 & 0 & 1 & 0 & 0 \\
\hline Hemiptera.Mesoveliidae & 0 & 0 & 1 & 0 & 0 \\
\hline Hemiptera.Pleidae & 0 & 0 & 1 & 0 & 0 \\
\hline Hemiptera.Saldidae & 0 & 0 & 1 & 0 & 1 \\
\hline Hemiptera.unknown & 1 & 1 & 0 & 1 & 0 \\
\hline Hemiptera.Veliidae & 0 & 0 & 1 & 1 & 1 \\
\hline Hymenoptera.Formicidae & 0 & 0 & 0 & 1 & 0 \\
\hline Hymenoptera.Diapriidae & 0 & 0 & 0 & 1 & 1 \\
\hline Hymenoptera.unknown & 0 & 1 & 0 & 1 & 1 \\
\hline Lepidoptera.Aphidae & 0 & 0 & 1 & 0 & 0 \\
\hline Lepidoptera.Pyralidae & 0 & 0 & 1 & 1 & 0 \\
\hline Megaloptera.Corydalidae & 0 & 0 & 1 & 0 & 1 \\
\hline Megaloptera.Sialidae & 0 & 0 & 1 & 1 & 1 \\
\hline Nematoda & 0 & 0 & 1 & 0 & 1 \\
\hline Odonata.Aeshnidae & 0 & 0 & 1 & 1 & 1 \\
\hline Odonata.Calopterygidae & 1 & 1 & 0 & 0 & 0 \\
\hline Odonata.Coenagrionidae & 0 & 1 & 1 & 0 & 0 \\
\hline Odonata.Cordulegastridae & 0 & 0 & 1 & 1 & 1 \\
\hline Odonata.Gomphidae & 0 & 0 & 1 & 1 & 1 \\
\hline Odonata.Lestidae & 1 & 1 & 0 & 0 & 0 \\
\hline Odonata.Libellulidae & 1 & 1 & 1 & 1 & 1 \\
\hline Oligochaeta.Lumbriculidae & 1 & 1 & 0 & 0 & 0 \\
\hline Pelecypoda.Sphaeriidae & 0 & 0 & 1 & 1 & 1 \\
\hline Pelecypoda.Unionidae & 0 & 0 & 0 & 1 & 0 \\
\hline Plecoptera.Capniidae & 0 & 0 & 0 & 1 & 1 \\
\hline Plecoptera.Chloroperlidae & 1 & 1 & 0 & 0 & 1 \\
\hline Plecoptera.Leuctridae & 0 & 0 & 1 & 1 & 1 \\
\hline Plecoptera.Nemouridae & 1 & 1 & 1 & 1 & 1 \\
\hline Plecoptera.Perlidae & 0 & 0 & 1 & 1 & 1 \\
\hline Plecoptera.Perlodidae & 1 & 1 & 1 & 1 & 1 \\
\hline Plecoptera.Pteronarcyidae & 0 & 0 & 1 & 1 & 1 \\
\hline Psocoptera.unknown & 1 & 1 & 0 & 1 & 0 \\
\hline Thysanoptera.Thripidae & 0 & 0 & 0 & 1 & 0 \\
\hline Trichoptera.Brachycentridae & 1 & 1 & 1 & 1 & 1 \\
\hline Trichoptera.Glossosomatidae & 0 & 0 & 1 & 1 & 1 \\
\hline Trichoptera.Goeridae & 1 & 1 & 0 & 0 & 0 \\
\hline Trichoptera.Helicopsychidae & 1 & 1 & 0 & 0 & 1 \\
\hline Trichoptera.Hydropsychidae & 1 & 1 & 1 & 1 & 1 \\
\hline Trichoptera.Hydroptilidae & 0 & 0 & 1 & 1 & 1 \\
\hline Trichoptera.Lepidostomatidae & 1 & 1 & 1 & 1 & 1 \\
\hline Trichoptera.Leptoceridae & 1 & 1 & 1 & 1 & 1 \\
\hline Trichoptera.Limnephilidae & 1 & 1 & 1 & 1 & 1 \\
\hline Trichoptera.Philopotamidae & 0 & 1 & 1 & 1 & 1 \\
\hline Trichoptera.Phryganeidae & 0 & 0 & 1 & 1 & 1 \\
\hline Trichoptera.Polycentropodidae & 1 & 1 & 1 & 1 & 1 \\
\hline Trichoptera.Psychomyiidae & 1 & 0 & 1 & 0 & 0 \\
\hline Trichoptera.Rhyacophilidae & 1 & 1 & 1 & 1 & 1 \\
\hline
\end{tabular}

\section{Appendix B.}

Common, taxonomic species names, and code (abbreviations) for species recorded at the single-basin and multiple-basin experimental sites in northern Minnesota. RC indicates the riparian control sites, INT indicates the intermediate RBA treatments, and Low indicates the low RBA treatments. A one indicates that the species was present in the treatment and a zero indicates an absence in the treatment. 


\begin{tabular}{|c|c|c|c|c|c|c|c|}
\hline \multirow[t]{2}{*}{ Common name } & \multirow[t]{2}{*}{ Taxonomic name } & \multirow[t]{2}{*}{ Code } & \multicolumn{2}{|c|}{ Single-basin experiment } & \multicolumn{3}{|c|}{ Multiple-basin experiment } \\
\hline & & & $\mathrm{RC}$ & INT & $\mathrm{RC}$ & INT & Low \\
\hline Brook Trout & Salvelinus fontinalis & BKT & 1 & 1 & 1 & 1 & 1 \\
\hline Blacknose Dace & Rhinicthys atratulus & BND & 0 & 0 & 1 & 1 & 1 \\
\hline Brook Stickleback & Culaea inconstans & BRS & 1 & 1 & 1 & 1 & 1 \\
\hline Blackside Darter & Percina maculata & BSD & 0 & 0 & 1 & 1 & 0 \\
\hline Burbot & Lota lota & BUB & 0 & 0 & 1 & 1 & 0 \\
\hline Mud Minnow & Umbra limi & CNM & 1 & 1 & 1 & 1 & 1 \\
\hline Common Shiner & Notropis cornutus & CNS & 0 & 0 & 1 & 0 & 0 \\
\hline Creek Chub & Semotilus atromaculatus & CRC & 1 & 1 & 1 & 1 & 1 \\
\hline Emerald Shiner & Notropis atherinoides & EMS & 0 & 0 & 1 & 1 & 0 \\
\hline Fine-scaled Dace & Phoxinus neogaeus & FSD & 1 & 1 & 1 & 0 & 1 \\
\hline Johnny Darter & Etheostoma nigrum & JOD & 0 & 0 & 1 & 1 & 0 \\
\hline Long-nosed Dace & Rhinicthys cataractae & LND & 0 & 0 & 1 & 1 & 1 \\
\hline Northern Red-bellied Dace & Phoxinus eos & NRD & 1 & 1 & 1 & 1 & 1 \\
\hline Pearl Dace & Semotilus margarita & PED & 0 & 0 & 1 & 0 & 0 \\
\hline Rainbow Trout & Oncorhynchus mykiss & RBT & 0 & 0 & 1 & 1 & 0 \\
\hline Slimy Sculpin & Cottus cognatus & SLS & 0 & 0 & 1 & 1 & 0 \\
\hline White Sucker & Catostomus commersoni & WHS & 0 & 0 & 1 & 1 & 1 \\
\hline
\end{tabular}

\section{References}

Anderson, P.D., Larson, D.J., Chan, S.S., 2007. Riparian buffer and density management influences on microclimate of young headwater forests of western Oregon. For. Sci. 53, 254-269.

Atuke, D.M., 2008. Effectiveness of riparian forestry best management practices to protect stream habitat and biota: lessons from temperate and tropical systems. Ph.D. Thesis. University of Minnesota, St. Paul, MN.

Barbour, M.T., Gerritsen, J., Snyder, B.D., Stribling, J.B., 1999. Rapid bioassessment protocols for Use in Streams and Wadeable Rivers: Periphyton, Benthic Macroinvertebrates and Fish, second ed. EPA 841-B-99-002. U.S. Environmental Protection Agency; Office of Water; Washington, D.C.

Barton, D.R., Taylor, W.D., Biettte, R.M., 1985. Dimensions of riparian buffer strips required to maintain trout habitat in southern Ontario streams. North Am. J. Fish. Manage. 5, 364-378.

Bêche, L.A., Mcelravy, E.P., Resh, V.H., 2006. Long-term seasonal variation in the biological traits of benthic-macroinvertebrates in two Mediterranean-climate streams in California USA. Freshwater Biol. 51, 56-75.

Bilby, R.E., Ward, J.W., 1991. Characteristics and function of large woody debris in streams draining old-growth clear-cut, and second-growth forests in southwestern Washington. Can. J. Fish. Aquat. Sci. 48, 2499-2508.

Blinn, C.R., Kilgore, M.A., 2001. Riparian management practices-a summary of state guidelines. J. Forest. 99, 11-17.

Broadmeadow, S., Nisbet, T.R., 2004. The effects of riparian forest management on the freshwater environment: a literature review of best management practices. Hydrol. Earth Syst. Sci. 8, 286-305.

Brown, A.V., Aguila, Y., Brown, K.B., Fowler, W.P., 1997. Responses of benthic macroinvertebrates in small intermittent streams to silvicultural practices. Hydrobiologia 347, 119-125.

Carroll, G., Schoenholtz, S., Young, B., Dibble, E., 2004. Effectiveness of forestry streamside management zones in the sand-clay hills of Mississippi: early indications. Water Air Soil Pollut. 4, 275-296.

Davies, P.E., Nelson, M., 1994. Relationships between riparian buffer widths and the effects of logging on stream habitat, invertebrate community composition and fish abundance. Aust. J. Mar. Fresh. Res. 45, 1289-1305.

de Graaf, M., Roberts, M.R., 2008. Short-term response of the herbaceous layer within leave patches after harvest. For. Ecol. Manage. 257, 1014-1025.

Goebel, P.C., Palik, B.J., Pregitzer, K.S., 2003. Plant diversity contributions of riparian areas in watersheds of the northern lakes states, USA. Ecol. Appl. 13, 1595-1609.

Gomi, T., Sidle, R.C., Richardson, J.S., 2002. Understanding processes and downstream linkages of headwater systems. Bioscience 52, 905-916.

Grossman, G.D., Dowd, J.F., Crawford, M., 1990. Assemblage stability in stream fishes: a review. Environ. Manage. 14, 661-671.

Hawkins, C.P., Murphy, M.L., Anderson, N.H., 1982. Effect of canopy, substrate composition, and gradient on the structure of macroinvertebrate communities in cascade range streams of Oregon. Ecology 63, 1840-1856.

Hemstad, N.A., Merten, E.C., Newman, R.M., 2008. Effects of riparian forest thinning by two types of mechanical harvest on stream fish and habitat in northern Minnesota. Can. J. Forest Res. 38, 247-256.

Johnson, S.L., Jones, J.A., 2000. Stream temperature responses to forest harvest and debris flows in western Cascades, Oregon. Can. J. Fish. Aquat. Sci. 57, 30-39.

Kastendick, D.N., 2005. Riparian forest management in northern Minnesota: effects of riparian silvicultural treatments on forest biomass, structure, composition, and indices of plant available nutrients. MSc Thesis. University of Minnesota, Saint Paul, MN.

Kedzierski, W.M., Smock, L.A., 2001. Effects of logging on macroinvertebrate production in a sand-bottomed, low-gradient stream. Freshwater Biol. 46, $821-833$

Kiffney, P.M., Richardson, J.S., Bull, J.P., 2003. Responses of periphyton and insects to experimental manipulation of riparian buffer width along forest streams. J. Appl. Ecol. 40, 1060-1076.
Kindt, R., Coe, R., 2005. Tree Diversity Analysis. A Manual and Software for Common Statistical Methods for Ecological and Biodiversity Studies. World Agroforestry Centre (ICRAF), Nairobi.

Lee, P., Smyth, C., Boutin, S., 2004. Quantitative review of riparian buffer width guidelines from Canada and the United States. J. Environ. Manage. 70, 165-180.

Magurran, A.E., 2004. Measuring Biological Diversity. Blackwell Publisher, Malden, MA

Merritt, R.W., Cummins, K.W., 1996. An Introduction to the Aquatic Insects of North America. Kendall Hunt, Dubuque, IA

Minnesota Forest Resources Council, 1999. Sustaining Minnesota Forest Resources: Voluntary Site-level Forest Management Guidelines for Landowners, Loggers and Resource Managers. Minnesota Forest Resources Council, St. Paul, MN.

Murphy, M.L., Koski, K.V., 1989. Input and depletion of woody debris in Alaska streams and implications for streamside management. North Am. J. Fish. Manage. 9, 427-436.

Mykrä, H., Heino, J., Muotka, T., 2008. Concordance of stream macroinvertebrate assemblage classifications: how general are patterns from single-year surveys? Biol. Conserv. 141, 1218-1223.

Naiman, R.J., Décamps, H., 1997. The ecology of interfaces: riparian zones. Annu. Rev. Ecol. Syst. 28, 621-658.

Naiman, R.J., Décamps, H., Pollock, M., 1993. The role of riparian corridors in maintaining regional biodiversity. Ecol. Appl. 3, 209-212.

Newbold, J.D., Erman, D.C., Roby, K.B., 1980. Effects of logging on macroinvertebrates in streams with and without buffer strips. Can. J. Fish. Aquat. Sci. 37, 1076-1085.

Nislow, K.H., Lowe, W.H., 2006. Influences of logging history and riparian forest characteristics on macroinvertebrates and brook trout (Salvelinus fontinalis) in headwater streams (New Hampshire, U.S.A.). Freshwater Biol. 51, 388-397.

Noel, D.S., Martin, C.W., Federer, C.A., 1986. Effects of forest clearcutting in New England on stream macroinvertebrates and periphyton. Environ. Manage. 10, 661-670.

Olden, J.D., Jensen, O.P., Vander Zanden, M.J., 2006. Implications of long-term dynamics of fish and zooplankton communities for among-lake comparisons. Can. J. Fish. Aquat. Sci. 63, 1812-1821.

Olson, D.H., Anderson, P.D., Frissell, C.A., Welsh Jr., H.H., Bradford, D.F., 2007. Biodiversity management approaches for stream-riparian areas: perspectives for Pacific Northwest headwater forests, microclimates, and amphibians. For. Ecol. Manage. 246, 81-107.

Omernik, J.M., Gallant, A.L., 1988, Ecoregions of the Upper Midwest states. EPA/600/3-88/037. U.S. Environmental Protection Agency, Corvallis, OR.

Palik, B., Cease, K., Egeland, L., Blinn, C., 2003. Aspen regeneration in riparian management zones in northern Minnesota: effects of residual overstory and harvest method. North. J. Appl. For. 20, 79-84.

Palik, B.J., Zasada, J.C., Hedman, C.W., 1999. Ecological principles for riparian silviculture. In: Verry, E.S., Hornbeck, J.W., Dolloff, C.A. (Eds.), Riparian Management in Forests of the Continental Eastern United States. Lewis Publishers, Boca Raton, FL, pp. 233-254

Palmer, M.A., Allan, J.D., Butman, C.A., 1996. Dispersal as a regional process affecting the local dynamics of marine and stream benthic invertebrates. Trends Ecol. Evol. 11, 322-326.

Perala, D.A., 1977. Managers' handbook for aspen in the north-central states. Technical Report NC-36. USDA Forest Service, North Central Forest Experiment Station, St. Paul, MN.

Pinheiro, J., Bates, D., DebRoy, S., Sarkar, D., the R Core team, 2009. nlme: Linear and Nonlinear Mixed Effects Models. R package version 3.1-91.

Quinn, J.M., Boothroyd, I.K.G., Smith, B.J., 2004. Riparian buffers mitigate effects of pine plantation logging on New Zealand streams: 2. Invertebrate communities. For. Ecol. Manage. 191, 129-146.

Richardson, J.S., Danehy, R.J., 2007. A synthesis of the ecology of headwater streams and their Riparian Zones in temperate forests. For. Sci. 53, 131-147.

Robinson, C.T., Uehlinger, U., Hieber, M., 2001. Spatio-temporal variation in macroinvertebrate assemblages of glacial streams in the Swiss Alps. Freshwater Biol. 46, $1663-1672$. 
Rykken, J.J., Moldenke, A.R., Olson, D.H., 2007. Headwater riparian forest-floor invertebrate communities associated with associated with alternative forest management practices. Ecol. Appl. 17, 1168-1183.

Simpson, E., 1949. Measurement of diversity. Nature 163, 688.

Smith, B., Wilson, J.B., 1996. A consumer's guide to evenness indices. Oikos 76, 70-82.

Smokorowski, K.E., Pratt, T.C., 2007. Effect of a change in physical structure and cover on fish and fish habitat in freshwater ecosystems-a review and meta-analysis. Environ. Rev. 15, 15-41.

Stone, M.K., Wallace, J.B., 1998. Long-term recovery of a mountain stream from clearcut logging: the effects of forest succession on benthic invertebrate community structure. Freshwater Biol. 39, 151-169.
Wang, X., Burns, D.A., Yanai, R.D., Briggs, R.D., Germain, R.H., 2006. Changes in stream chemistry and nutrient export following a partial harvest in the Catskill Mountains, New York, USA. For. Ecol. Manage. 223, 103-112.

Whittaker, R.H., 1965. Dominance and diversity in land plant communities: numerical relations of species express the importance of competition in community function and evolution. Science 147, 250.

Wiens, J.A., 1981. Single-sample surveys of communities: are the revealed patterns real? Am. Nat. 117, 90.

Wilkerson, E., Hagan, J.M., Siegel, D., Whitman, A.A., 2006. The effectiveness of dif ferent buffer widths for protecting headwater stream temperature in Maine. Forest Sci. 52, 221-231. 